\title{
Marketing Strategies for E-commerce Websites Under the New Media Trend
}

\begin{abstract}
Yinlu Li
${ }^{1}$ University of California, Santa Barbara

*Corresponding author. Email: liyinlu1@gmail.com

ABSTRACT

With the continuous development of information technology in China, it has become an indispensable part in the daily life and production. As an economic model based on extended information technology, E-commerce technology has gradually been accepted by the public, from the traditional passive acceptance to active cooperation and active use, which serves as an opportunity as well as a challenge for e-commerce enterprises. They must ensure good performance in marketing, such as website marketing. Website marketing is an essential part of the e-commerce marketing process, and its level will directly determine the overall operation quality and efficiency of e-commerce enterprises. Therefore, the relevant staff must conduct in-depth research on it, optimize and innovate traditional marketing methods in the context of new media technology, improve the level of website marketing, to improve the influence of enterprises in all aspects and enable them to obtain a certain share in the e-commerce market. Based on this, this thesis makes an in-depth analysis of e-commerce website marketing against the backdrop of new media and formulates corresponding marketing strategies according to its characteristics.
\end{abstract}

Keywords: new media, e-commerce website, marketing strategy

\section{INTRODUCTION}

In recent years, China's e-commerce industry has developed well, especially the new media industry, which has opened a new economic development model for China's e-commerce industry. E-commerce website marketers must take the new media era as the background in their daily marketing, continuously improve the traditional marketing methods, scientifically and rationally adjust their marketing programs with the trend of China's social development and the public's psychological needs, update products and inject freshness and vitality into products, to stimulate consumers' interest and enable them to have trust in the website and a sense of dependence on products. This will improve the overall quality and efficiency of e-commerce enterprises, promote the longterm development of China's e-commerce industry, and lay the foundation for China's national economic growth.

\section{CHARACTERISTICS OF THE E- COMMERCE WEBSITE MARKETING UNDER THE NEW MEDIA TREND}

\subsection{Diversity}

New media marketing means are richer in content carriers compared with traditional marketing means, such as music, text, pictures, video, animation. The advantages of electronic information technology can be fully leveraged, and the public can quickly find the information they need in the corresponding information. When using new media marketing tools for e-commerce website marketing, marketers can add the corresponding marketing information to the audio or video, to promote information dissemination and enrich the content [1]. Therefore, new media marketing tools are more flexible and diverse in that they can break the traditional ways of marketing, improve the appeal of the product, open new ideas for e-commerce marketing innovation and effectively catch consumers' attention. 


\subsection{Popularity}

As a product of the development of Internet technology, new media has gradually become mainstream. At present, China is one of the countries with the largest number of mobile internet users. As one of the important means to improve the promotion and application of new media technology, new media marketing means can bring information to the public through cell phones and the Internet, ensuring the public to absorb the information when using mobile phones and the Internet [2]. Therefore, the new media ecommerce website marketing means can be widely accepted and applied by the public with wide popularity.

\subsection{Flexibility and interactivity}

E-commerce website marketing enjoys greater flexibility and interactivity than traditional website marketing with background of new media technology. Staffs can use big data for accurate marketing and promote their products according to the needs of different consumer groups. Consumers can filter product information according to their actual needs, so as to obtain the corresponding products, which effectively improve the interaction between enterprises and consumers. In addition, new media marketing technology is a marketing activity mainly based on information technology free from time and place restrictions, allowing the public to use cell phones and the Internet for corresponding products at their leisure, which improves the flexibility of product sales [3].

\section{THE NECESSITY OF DEVELOPING E- COMMERCE WITH BACKGROUND OF NEW MEDIA}

\subsection{Significance}

Carrying out daily marketing by new media means, E-commerce website marketing staffs can transform original targeted groups into potential customers. For ecommerce enterprises, they not only need to ensure the quality of their products but publicity in order to display the properties of the product, draw consumers' interests and develop their trust in the product. By doing so, the overall sales of the product will witness an increase. New media marketing methods have greater specificity and can avoid the untimeliness and inaccuracy in all aspects compared with traditional ones. Thus, they can dig deeper into the potential users and improve the adhesion between enterprises and consumers. When using new media technology for website marketing, staffs should allow consumers to read the corresponding to convey product information, so as to tap potential customers and improve the overall quality and efficiency of business operations.

\subsection{Trends}

Nowadays, China's market economy has entered the era of globalization with well-developed information technology penetrating into the daily life and production. In this context, new media technology comes into being, serving as one of the important means in the current e-commerce website marketing process, which can effectively improve the overall quality and efficiency of e-commerce website marketing. It can accumulate a large customer base for e-commerce websites thanks to its high dissemination rate and wide coverage compared with the traditional one. In addition, it helps staffs to explore potential customers and laying a good customer flow foundation. At the same time, consumers will also play a certain role in transmission when browsing the corresponding information, which can effectively improve the wide spread of e-commerce website marketing. What's more, as China has entered the digital era, the public's attention is gradually attracted by fragmented information, which is more interactive and infectious with lower marketing costs, so staffs can improve the overall marketing quality to a certain extent when using fragmented new media information for marketing and publicity. By so doing, ecommerce websites can quickly adapt to the new media environment and improve overall development benefits of the enterprise.

\section{EFFECTIVE STRATEGIES TO IMPROVE THE LEVEL OF E- COMMERCE WEBSITE MARKETING WITH BACKGROUND OF NEW MEDIA}

\subsection{Define the labor division}

In order to ensure the stable operation of the ecommerce website, the leaders must divide the work of employees according to the actual work requirements, so as to ensure that every employee can understand the specific content of their own work and each process can be developed in a coordinated manner, thus improving the overall quality of the e-commerce website in all aspects and laying the foundation for the improvement of its marketing level. Staffs for product updating need to timely integrate the content of the website and scientifically adjust its products according to social development and public consumption psychology. By so doing, consumers can maintain a permanent sense of freshness to the e-commerce website, increase the website's views and enhance the overall marketing level. Besides, they also need to update the products in time to attract consumers' attention and enhance the connection between the e-commerce website and consumers [4]. In 
terms of the after-sales department, it is necessary to ensure the staffs' service attitude and reply to consumers' questions in time to become trustworthy, in the end achieving a relatively high conversion rate, increasing traffic and improving the quality and efficiency of the operation of the business website [5].

\subsection{Increase Traffic}

During the daily marketing of e-commerce website with background of new media, it is not only necessary to ensure the quality of its products to meet the public demand, but also to improve the comprehensive quality of professional staffs and increase traffic. Staffs can make a corresponding attraction post to attract consumers' attraction in terms of e-commerce marketing, so as to lay a foundation for the development of the website. Attraction posts can accumulate view of the e-commerce website, so that consumers will develop a sense of trust and dependence on the website, thus improving the overall marketing level. In addition, staffs should pay attention to titles which are essential for posts in that an appealing title can stimulate the interest of viewers to increase views and reposts, increase traffic and improve the overall marketing. It should be noted that staffs are supposed to polish the title according to the actual situation in order to avoid improper titles which may lead to consumers' negative impact on the article, such as resistance mentality. In such case, it is impossible to play the role of posts in increasing website views. Even worse, the development of the website will be subject to hinderance. Therefore, it's necessary to innovative titles in combination with consumers' reading habits and product characteristics. When writing articles, it is important to base on the characteristics of the product itself and the events that consumers care about, including hot spots, personal experiences of consumers, etc., to strike a chord with the viewers and develop their sense of trust. As a result, it helps increase traffic to the website and provide data support for the website marketing level.

\subsection{Build brand value}

The consumption mentality of customers in daily life has changed significantly with stronger curiosity and larger demand as well as lower patience.

The main reason for this phenomenon is the rapid development of information technology in China with all kinds of information springing up. As a result, consumers prefer to information they are interested in among the huge flow. Besides, due to overfragmentation, their patience for articles and information is gradually reduced. Therefore, staffs of ecommerce website must make scientific and reasonable innovation based on the consumer's consumption characteristics as well as focus on brand building based on users' mentality to fully reflect the brand value, draw their interest and develop their sense of trust in goods. By this way, it can improve the overall effect of the product and brand, allowing it to be transmitted among consumers, achieving traffic increase for the second time, promoting brand influence so as to improve the overall effect of the brand and provide support for ecommerce marketing.

\subsection{Enhance the functionality of the website}

Websites' functionality is not only one of the main measures to reflect the professional level of e-commerce enterprises, but also the key to attract consumers' attention and increase their interest in consumption. Therefore, staffs need to fully reflect the professionalism of the website when introducing products using the e-commerce website, so as to ensure that consumers can have a sense of belonging to the website and a sense of trust in the products. Also, they are supposed to fully explore the consumption potential and increase connections with customers to enable them to take the initiative to purchase goods, thus improving the overall marketing level of the website. Generally speaking, consumers will focus on the quality of goods and after-sales service, so the website staffs must ensure that the pictures match the goods when integrating the website information. Besides they should demonstrate the quality of goods through the website, interact with consumers through the corresponding section, and improve the overall quality and efficiency of after-sales service, such as the through-train section. It should also be noticed that module-based website design can not only carry out scientific and reasonable classification of goods, but also reflect the professionalism of ecommerce enterprises, increase their trust in the enterprise, provide them reassurance, improve the overall marketing level of the website, optimize and innovate its business methods, form a good reputation, and lay the foundation for improve its marketing level.

\subsection{Deliver precision marketing}

Big data is one of the main features of the new media era, so e-commerce marketers need to fully leverage big data and reflect the advantages of the network information technology and data platform when engaging in website marketing with background of new media. They are encouraged to comprehensively analyze consumption habits and psychological needs with big data prior to formal marketing. Also, they should reform their services according to consumption habits to deliver customized and personalized services, so as to recommend products of interest to consumers and realize precise marketing. As precision marketing will involve a large number of consumers' information, 
staffs must carry out scientific and reasonable protection of user privacy based on information network security, so as to avoid the leakage of consumer information and the loss of customers' trust. Otherwise, it could be extremely unfavorable to the development of the website. Using targeted marketing to improve the quality of goods while creating a satisfying shopping atmosphere, marketers can enhance customers' trust, thereby improving the overall marketing level of the website.

\subsection{Cultivate high quality talents}

E-commerce website marketing in the era of new media requires talents with high comprehensive quality. So leaders must ensure corresponding training in the daily work and improve professional theoretical literacy of staffs. To this end, leaders can regularly invite professionals to conduct training based on the actual work of the website, and provide targeted training for website staff based on their actual work, so as to improve the staffs' overall quality. As the actual operation of the e-commerce website involves many types of work, such as website customer service, sales, etc., so leaders must carry out scientific and rational training based on job nature, so as to improve the level of talent cultivation, such as website customer service. As a part of service industry, the comprehensive quality of staffs in website customer service will directly determine the development of consumer companies and is essential for consumer cohesion. Therefore, leaders need to ensure that their professionalism can meet consumers' demand in terms of answering customers' questions with patience and responsibility and showing the enterprise's image. Leaders can conduct pre-job training for customer service staffs before official work, so that they can fully understand the content of their work and realize its importance in an all-round way. At the same time, sales staff's marketing methods will directly determine the overall level of e-commerce websites. Therefore, leaders also need to ensure training for sales staffs based on consumers' mentality. By doing so, it can ensure that sales staff meet consumers' demand when formulating promotion plans, so as to attract consumers' attention, improve the overall marketing level of sales staffs, and further enhance the overall marketing quality and efficiency of e-commerce websites. In addition, leaders should make efforts to attract talents. Leaders can cooperate with colleges and universities, so that college teachers can understand the overall operation of e-commerce companies today, and train talents according to the actual needs of the company to improve students' professional capabilities as well as infuse new blood into e-commerce companies' talent teams.

\section{CONCLUSION}

In conclusion, nowadays, China has fully marched into the new media era, e-commerce enterprises must be committed to reforms if they want to achieve long-term development, constantly innovating their marketing programs against the background of the new media era and carrying out all-round marketing from different aspects based on social development trends and consumers' psychological characteristics. By doing so, they are expected to improve the vitality of products, attract consumers' attention and enable consumers to have a sense of dependence on products, increase the product dissemination rate, lay the foundation for product sales and enable e-commerce enterprises to carry out benign development. In the end, they can lay the foundation for the stable and long-term development of e-commerce in China.

\section{REFERENCES}

[1] Zhang Mengyao. Research on new media marketing strategy of mobile e-commerce [J]. Modern Marketing (Business Edition),2021(05):78-79.

[2] Hou Yuying. Interpretation of e-commerce network soft copy marketing strategy under new media conditions [J]. Shanxi Agricultural Economics,2017(16):84-85.

[3] Li Zhaohong. Application of new media marketing tools (microblogs and weibo) in e-commerce websites in Jilin Province [J]. Enterprise Herald,2016(15):113.

[4] Liu Fang. Analysis of e-commerce network soft marketing strategy under new media conditions $[\mathrm{J}]$. Journal of Chaohu College,2013,15(05):34-36+54.

[5] Oliver, M. B., \& Bartsch, A. (2011). Appreciation of entertainment. Journal of Media Psychology. 